over the surface of the cleft between the two lobes (Fig. 1a, shown in red) and in doing so traverses the entire protein substrate binding groove as well as occupying a substantial region of the ATP-binding site as it wedges between the two lobes. Inspection of the contacts between the $\mathrm{C}$-terminal residues and the catalytic core reveals 47 hydrogen bonds $(<3.5 \AA)$ and 351 van der Waals contacts $(<4 \AA)$. A number of contacts mimic those expected for peptide substrate side-chain recognition sites, others involve residues in the ATP-binding glycine-rich loop and residues involved in catalysis conserved in all protein kinases ${ }^{7,14}$ (Fig. 2).

The twitchin kinase structure provides compelling evidence of the intrasteric model of protein kinase regulation with the autoregulatory sequence exploiting multiple features of the enzyme's active site to inhibit enzyme activity; indeed it mirrors the active site and is more than a simple pseudosubstrate. Preliminary work suggests the mechanism revealed here will be shared by all members of the MLCK and calmodulin-dependent protein kinase II subfamilies and possibly other enzymes.

\footnotetext{
Received 21 February; accepted 15 April 1994.

1. Kemp, B. E. \& Pearson, R. B. Biochim. biophys. Acta 1094, 67-76 (1991).

2. Kemp, B. E. et al. in Protein Kinases: Frontiers in Molecular Biology (ed. Woodgett, J.) (Oxford Univ. Press, London, in the press).

3. Benian, G. M., Kiff, J. E., Neckleman, N., Moerman, D. G. \& Waterson, R. H. Nature 342, 45-50 (1989).

4. Benian, G. M., L.Hernault, S. W. \& Morris, M. E. Genetics 134, 1097-1104 (1993).

5. Waterston, R. H., Thomson, J. N. \& Brenner, S. Devl Biol. 77, 271-302 (1980).

6. Knighton, D. R. et al. Science 253, 407-414 (1991).

6. Knighton, D. R. et al. Science 253, 407-41.4 (1991).
7. Knighton, D. R. et al. Science 253, 414-420 (1991).

7. Knighton, D. R. et al. Science 253, $414-420$ (1991). (1993).

9. De Bondt, H. L. et al. Nature 363, 595-602 (1993).

10. Knighton, D. R. et al. Acta crystallogr. D49, 357-361 (1993).

11. Olah, G. A., Mitchell, R. D., Sosnich, T. R., Walsh, D. A. \& Trewhella, J. Biochemistry 32, 3649-3657 (1993).

12. Gerstein, M. et at J. molec. Biol. 234, 357-372 (1993).

13. Knowles, J. R. Nature 350, 121-124 (1991).

14. Zheng, J. et al. Biochemistry 32, 2154-2161 (1993).

15. Hu, S.-H. et al. J. molec. Biol. 236, 1259-1261 (1994)

16. Kabsch, W. J. appl. Crystallogr. 21, 916-924 (1988).

17. Vellieux, F. M. D. et al. Proc. natn. Acad. Sci. U.S.A. 90, 2355-2359 (1993).

18. Jones, T. A. J. appl. Crystallogr. 11, 268-274 (1978).

19. Brunger, A. T., Kuriyan, J. \& Karplus, M. Science 235, 458-460 (1987).

20. Hendrickson W. A. \& Konnert, J. M. in Computing in Crystallography (eds Diamond, R Ramaseshan, S. \& Venkatesan, K.) 13.01-13.23 (Indian Academy of Science, Int. Union of Crystallography, Bangalore, 1980)

21. Kraulis, P. J. J. appl. Crystallogr. 24, 946-950 (1991).

22. Kabsch, W. \& Sander, C. Biopolymers 22, 2577-2637 (1983).

23. Zheng. J. et al. Acta crystallogr. D49, 362-365 (1993).
}

ACKNOWLEDGEMENTS. We thank D. Knighton, J. Sowadski and S. Tayior for providing refined coordinates of the CAPK structure and J. Janis for assistance in the preparation of the colour figures. G.M.B. is an Established Investigator of the American Heart Association, M.W.P. is a figures. G.M.B. is an Established investigator of the American Heart Association, M.W.P. is a
Wellcome Australian Senior Research Fellow and B.E.K. is an NH \& MRC Research Fellow. This Wellcome Australian Senior Research Fellow and B.E.K. is an NH \& MRC Research Fellow. This
work was supported by the National Health and Medical Research Council of Australia (B.E.K. and M.W.P.), National Heart Foundation (B.E.K.) and the NIH (G.M.B.).
CORRECTIONS

The shape, expansion rate and distance of supernova 1993J from VLBI measurements

\author{
N. Bartel, M. F. Bietenholz, M. P. Rupen, \\ J. E. Conway, A. J. Beasley, R. A. Sramek, \\ J. D. Romney, M. A. Titus, D. A. Graham, \\ V. I. Altunin, D. L. Jones, A. Rius, T. Venturl, \\ G. Umana, R. L. Francis, M. L. McCall, \\ M. G. Richer, C. C. Stevenson, K. W. Weiler, \\ S. D. Van Dyk, N. Panagia, W. H. Cannon, \\ J. Popelar \& R. J. Davis
}

Nature 368, 610-613 (1994)

IN this letter some of the references were incorrectly numbered (details available from the first author).

\section{Water-based non-stick hydrophobic coatings}

\section{Donald L. Schmidt, Charles E. Coburn, Benjamin M. DeKoven, Gregg E. Potter, Gregory F. Meyers \& Daniel A. Fischer}

Nature 368, 39-41 (1994)

THE chemical nomenclature used for monomer $\mathrm{A}$ in this letter should have been correctly given as 2-(perfluorooctyl)ethyl methacrylate (recommended common name) or 1-decanol, $3,3,4,4,5,5,6,6,7,7,8,8,9,9,10,10,10$ - heptadecafluoro - methacryl ate (Chemical Abstracts complete name). 